\title{
Penerapan Regresi Logistik Biner Dalam Menentukan Determinan Pengangguran Usia Muda Terdidik di Provinsi Banten
}

Apriliansyah

Politeknik Statistika STIS, 211709567@stis.ac.id

Muti Nurjannah Fitri

Politeknik Statistika STIS,211709875@stis.ac.id

Sabiq Sofyan

Politeknik Statistika STIS, 211709993@stis.ac.id

Syifa Rahmawati Hakim

Politeknik Statistika STIS, 211710025@stis.ac.id

Tiodora Hadumaon Siagian

Politeknik Statistika STIS, theo@stis.ac.id

\begin{abstract}
ABSTRAK, Pemanfaatan era bonus demografi tidak bisa tercapai jika tidak diimbangi dengan peningkatan kualitas dan pemberdayaan sumber daya manusia yang tersedia. Salah satu indikator yang seringkali digunakan dalam mengukur pemberdayaan sumber daya manusia, yaitu TPT (Tingkat Pengangguran Terbuka). Provinsi Banten menempati posisi pertama dengan TPT tertinggi di Indonesia pada tahun 2019 sebesar 8,11 persen. Selain itu, sebagian besar pengangguran di Banten memiliki pendidikan terakhir SMA/sederajat yakni sebesar 65,15 persen. Selain pemberdayaan SDM terdidik yang kurang optimal, potensi sumber daya manusia usia muda (15-29 tahun) juga belum sepenuhnya terserap dalam pasar kerja. Persentase pemuda yang menganggur di Banten menempati posisi kedua tertinggi, yaitu sebesar 11,45. Oleh karena itu, penelitian ini bertujuan untuk mengetahui faktor-faktor yang memengaruhi pengangguran terdidik di kalangan pemuda di Provinsi Banten menggunakan analisis regresi logistik biner. Data penelitian bersumber dari data sekunder BPS, yaitu Survei Angkatan Kerja Nasional (Sakernas) Agustus 2019 untuk mengetahui faktor-faktor yang memengaruhi pengangguran terdidik di kalangan pemuda. Hasil penelitian menunjukkan variabel wilayah tempat tinggal, jenis kelamin, umur, dan status perkawinan berpengaruh signifikan terhadap status bekerja angkatan kerja usia muda terdidik di Provinsi Banten pada tahun 2019.
\end{abstract}

Kata Kunci: pengangguran, terdidik, pemuda, regresi logistik, Banten

\section{PENDAHULUAN}

Indonesia diprediksi akan mengalami fenomena puncak bonus demografi pada tahun 2030 akibat dari adanya transisi demografi (kondisi kependudukan mengalami perubahan). Bonus demografi merupakan momentum ketika penambahan jumlah penduduk usia kerja (produktif) karena adanya penurunan rasio beban ketergantungan. Rasio ketergantungan menunjukkan pengaruh potensial dari adanya perubahan struktur umur penduduk Indonesia terhadap pembangunan (BPS, 2010). Ketika rasio beban ketergantungan mencapai titik terendah atau berada di bawah 50 persen disebut The Window of Opportunity (Jendela Peluang). Kondisi tersebut yakni penduduk usia produktif (15-64 tahun) lebih banyak dibandingkan penduduk tidak produktif $(<15$ tahun dan $>64$ tahun). Jumlah penduduk usia produktif yang tinggi bisa menjadi sumber pertumbuhan ekonomi dalam arti mereka mampu menghasilkan pendapatan guna memenuhi konsumsi kebutuhan sehari-hari dan memiliki tabungan yang dapat dimobilisasi sebagai investasi negara (Maryati, 2015).

Jumlah penduduk produktif yang tinggi tidak menjamin akan keberhasilan bonus demografi yakni peningkatan produktivitas negara. Hal ini juga harus diimbangi dengan peningkatan kualitas dan pemberdayaan sumber daya manusia yang tersedia. Salah satu indikator yang seringkali digunakan dalam mengukur pemberdayaan sumber daya manusia, yaitu TPT (Tingkat Pengangguran Terbuka) (ILO, 2007). TPT merupakan indikator untuk mengukur persentase penduduk angkatan kerja yang berstatus menganggur. Jika membandingkan TPT setiap provinsi, masih banyak provinsi 
dengan TPT lebih tinggi dari TPT nasional, salah satunya provinsi dengan TPT tertinggi yaitu Banten. Berdasarkan data BPS diperoleh TPT Banten tahun 2019 sebesar 8,11 yakni 2,5 persen lebih tinggi dari TPT nasional 5,28. Selain itu, jika melihat komposisi penduduk yang menganggur sebagian memiliki latar belakang pendidikan yang tinggi (ijazah terakhir SMA/Sederajat). Berdasarkan data Sakernas 2019 persentase penduduk di Banten yang menyelesaikan pendidikan hingga minimum SMA/Sederajat meningkat juga sejalan dengan meningkatnya pengangguran dengan pendidikan terakhir jenjang SMA/Sederajat ke atas. Pada data sakernas agustus 2019 diperoleh persentase pengangguran yang tamat minimum SMA/Sederajat sebesar 65,15 persen yakni meningkat 4,25 persen dari tahun sebelumnya. Menurut Mankiw (2003) penduduk angkatan kerja yang sedang mencari pekerjaan ataupun belum menemukan pekerjaan dengan pendidikan terakhir minimum SMA/Sederajat disebut pengangguran terdidik.

Salah satu modal pemuda dalam mempersiapkan diri untuk ikut bersaing di dunia pasar kerja, yaitu mencari dan mengembangkan potensi diri melalui pendidikan. Umumnya pasar kerja di Indonesia menerima pekerja dengan minimum pendidikan tamatan SMA/Sederajat. Asumsi tersebut juga digunakan BPS dalam menyusun indikator Indeks Ketimpangan Gender (IKG) dalam aspek pemberdayaan penduduk, berlainan dengan rancangan United Nations Development Programme (UNDP) yang menggunakan minimum tamatan SMP/Sederajat. Meningkatnya jumlah penduduk usia kerja yang menyelesaikan pendidikan minimum SMA/sederajat diharapkan memudahkan mereka ikut bersaing di pasar kerja. Namun, masih tingginya jumlah pengangguran terdidik di kalangan pemuda bisa menjadi bumerang bagi negara sehingga tidak siap memanfaatkan peluang bonus demografi. Hal ini berdampak dalam produktivitas negara yang seharusnya meningkat pesat namun berujung menjadi beban ekonomi bagi keluarga dan negara. Urgensi dari fenomena ini dituangkan dalam Tujuan Pembangunan Berkelanjutan (TPB) pada target 18 yakni mewujudkan kesempatan kerja penuh dan produktif dan pekerjaan yang layak untuk semua termasuk kaum muda.

Di samping pemberdayaan SDM terdidik yang kurang optimal, ILO (2007) juga menyebutkan potensi SDM usia muda di Indonesia juga belum sepenuhnya terserap dalam pasar kerja. Salah satu masalah pembangunan pemuda di Indonesia yaitu pengangguran pemuda yang masih tinggi (BPS, 2019). Berdasarkan data BPS persentase pemuda yang menganggur menempatkan Banten di posisi kedua setelah Jawa Barat dengan persentase pemuda yang menganggur terbanyak di antara 34 provinsi lainnya, yaitu sebesar 11,45. Angka tersebut sedikit meningkat 0,18 dari tahun 2018 yang sebesar 11,22 tetapi juga berada diposisi tertinggi (BPS, 2018). Fenomena ini seringkali disebut pengangguran terdidik di kalangan pemuda. Menurut Indonesian Youth Employment Network (IYEN) menyebutkan penduduk usia muda (pemuda) memiliki rentang usia 15-29 tahun sehingga juga punya peran besar dalam keberhasilan bonus demografi di Indonesia. Oleh karena itu, berdasarkan latar belakang tersebut penelitian ini bertujuan untuk mengetahui faktor-faktor yang memengaruhi pengangguran terdidik di kalangan pemuda di Provinsi Banten.

\section{TINJAUAN PUSTAKA}

\section{Regresi Logistik Biner}

Regresi logistik biner merupakan metode analisis untuk menggambarkan hubungan variabel respon dengan satu atau lebih variabel prediktor. Variabel respon yang digunakan dibagi menjadi dua kategori, yaitu sukses $(\mathrm{Y}=1)$ dan gagal $(\mathrm{Y}=0)$. (Hosmer \& Lemeshow, 2000). E(Y|X) menyatakan sebuah dugaan dari hubungan antara variabel respon (Y) dengan variabel prediktor (X) yang memiliki nilai peluang antara 0 sampai dengan 1. $\mathrm{E}(\mathrm{Y} \mid \mathrm{x})$ dapat ditulis sebagai $\pi(\mathrm{x})$ yang menyatakan peluang terjadinya kejadian sukses yaitu pada saat $y=1$. Nilai $\pi(x)$ berkisar antara 0 sampai dengan $1(0 \leq \pi(\mathrm{x}) \leq 1)$. Berikut adalah bentuk umum untuk persamaan regresi logistik biner:

$$
g(x)=\beta_{0}+\beta_{1} x_{1}+\beta_{2} x_{2}+\ldots+\beta_{p} x_{p}
$$


Menurut Hosmer \& Lemeshow (2000), estimasi parameter pada regresi logistik biner dilakukan dengan metode Maximum Likelihood Estimator (MLE). Metode MLE menghasilkan nilai penduga parameter yang mampu memaksimalkan probabilitas dari kumpulan data observasi melalui sebuah fungsi likelihood. Fungsi likelihood untuk $\mathrm{n}$ sampel prediktor ialah sebagai berikut:

$$
l(\beta)=\prod_{i=1}^{n} \pi(x)^{y_{i}}\left[1-\pi\left(x_{i}\right)\right]^{1-y_{i}}
$$

Prinsip dari MLE adalah mencari penduga parameter yang mampu memaksimalkan fungsi likelihood pada persamaan (2), sehingga akan lebih mudah apabila menggunakan persamaan log likelihood sebagai berikut.

$$
\begin{aligned}
L(\beta)=\ln [l(\beta)] & =\sum_{i=1}^{n}\left\{y_{i} \ln \left[\pi\left(x_{i}\right)\right]\right. \\
& +\left(1-y_{i}\right) \ln [1 \\
& \left.\left.-\pi\left(x_{i}\right)\right]\right\}
\end{aligned}
$$

Dalam rangka mendapatkan nilai penduga terhadap $\beta$ yang mampu memaksimalkan $L(\beta)$, maka perlu dilakukan diferensial $L(\beta)$ pada persamaan (3) terhadap $\beta_{0}$ dan $\beta_{j}$, kemudian hasilnya disamakan dengan nol. Berdasarkan hasil tersebut, diperoleh persamaan likelihood sebagai berikut:

$$
\begin{aligned}
& \frac{\partial L(\beta)}{\partial\left(\beta_{0}\right)}=\sum_{i=1}^{n}\left[y_{i}-\pi\left(x_{i}\right)\right]=0 \\
& \frac{\partial L(\beta)}{\partial\left(\beta_{j}\right)}=\sum_{i=1}^{n} x_{i j}\left[y_{i}-\pi\left(x_{i}\right)\right]=0
\end{aligned}
$$

keterangan:

$\mathrm{i}=1,2, \ldots, \mathrm{n}$; dimana $\mathrm{n}$ merupakan banyaknya observasi

$\mathrm{j}=1,2, \ldots, \mathrm{p}$; dimana $\mathrm{p}$ adalah banyaknya parameter

Pada metode regresi logistik, persamaan (2.4) dan (2.5) adalah persamaan yang nonlinear terhadap $\beta_{0}$ dan $\beta_{1}$. Sehingga untuk memperoleh estimasi parameter dengan metode MLE, dibutuhkan proses iterasi dengan bantuan software statistik.

\section{Uji Signifikansi Parameter}

Uji signifikansi parameter pada regresi logistik dapat dilakukan secara simultan dan parsial. Uji signifikansi simultan dilakukan dengan menggunakan Uji Rasio Likelihood (Likelihood Ratio Test). Hipotesis yang digunakan dalam pengujian ini adalah sebagai berikut:

$\mathrm{H}_{0}: \beta_{1}=\beta_{2}=\ldots=\beta_{p}=0$

$\mathrm{H}_{1}$ : minimal terdapat satu $\beta_{j} \neq 0$, dengan $\mathrm{j}=1,2, . ., p$

dengan statistik uji:

$$
G=-2 \ln \left[\frac{L_{0}}{L_{1}}\right]=-2\left(\ln L_{0}-\ln L_{1}\right)
$$

keterangan:

$L_{0}=$ nilai likelihood dari model tanpa variabel bebas (hanya intersep saja)

$L_{1}=$ nilai likelihood dari model dengan variabel bebas

Kriteria pengujian yang dilakukan ialah $\mathrm{H}_{0}$ akan ditolak apabila $\mathrm{G}>\chi_{\alpha, p}^{2}$ atau $\mathrm{p}$-value $<\alpha$ (Hosmer \& Lemeshow, 2000).

Selanjutnya uji signifikansi parameter secara parsial dilakukan untuk mengetahui pengaruh dari masing-masing variabel prediktor terhadap variabel respon. Statistik uji yang digunakan pada uji parsial ini adalah statistik uji Wald (W). Adapun hipotesis yang digunakan ialah sebagai berikut:

$\mathrm{H}_{0}: \beta_{j}=0$, dengan $\mathrm{j}=1,2, \ldots, \mathrm{p}$

$\mathrm{H}_{1}: \beta_{j} \neq 0$, dengan $\mathrm{j}=1,2, \ldots, \mathrm{p}$

dengan statistik uji:

$$
W_{j}=\left(\frac{\hat{\beta}_{j}}{S E\left(\hat{\beta}_{j}\right)}\right)^{2} ; \mathrm{j}=1,2, \ldots, \mathrm{p}
$$

keterangan:

$\hat{\beta}_{j} \quad=$ penduga parameter $\beta_{j}$

$\operatorname{SE}\left(\hat{\beta}_{j}\right)=$ penduga standard error dari $\beta_{j}$

$\mathrm{p} \quad=$ banyaknya variabel prediktor

Kriteria pengujian yang digunakan ialah menolak $\mathrm{H}_{0}$ pada tingkat signifikansi $\alpha$ apabila $\left|W_{j}\right|>Z_{\frac{\alpha}{2}}$ atau $p$-value $<\alpha$.

\section{Uji Goodness Of Fit}

Uji kesesuaian model atau disebut juga Goodness of Fit Test merupakan uji yang dilakukan untuk 
mengetahui bahwa model yang digunakan dalam penelitian telah sesuai/fit dalam menjelaskan variabel respon. Uji kesesuaian model dapat dilakukan dengan berdasarkan pada hipotesis sebagai berikut:

H0: Model yang dibentuk fit

H1: Model yang dibentuk tidak fit

Statistik uji yang digunakan adalah The HosmerLemeshow Test dengan rumus sebagai berikut:

$$
\hat{C}=\sum_{k=1}^{g} \frac{\left(o_{k}-n^{\prime}{ }_{k} \bar{\pi}_{k}\right)^{2}}{n^{\prime}{ }_{k} \bar{\pi}_{k}\left(1-\bar{\pi}_{k}\right)}
$$

Keputusan yang diambil akan menolak $\mathrm{H}_{0}$ pada tingkat signifikansi $\alpha$ apabila $\hat{C}>\chi_{\alpha, g-2}^{2}$ atau $p$ value $<\alpha$.

\section{Pengangguran Usia Muda Terdidik}

Pengangguran usia muda terdidik yang dimaksud pada penelitian ini merupakan gabungan dari dua konsep, yaitu pengangguran terdidik dan pengangguran usia muda. Usia muda yang dimaksud dalam penelitian ini merujuk pada konsep yang digunakan oleh IYEN, yaitu kelompok yang berada pada usia 15-29 tahun. Kemudian Mankiw (2003) menyatakan bahwa yang dimaksud dengan pengangguran terdidik merupakan seseorang yang sedang mencari pekerjaan atau belum bekerja namun memiliki pendidikan SMA ke atas. Adapun faktor-faktor yang diduga memengaruhi pengangguran usia muda terdidik ialah sebagai berikut:

a. Wilayah Tempat Tinggal

Variabel wilayah tempat tinggal amat berkaitan dengan fenomena pengangguran terdidik (Putri \& Aimon, 2019) dan pengangguran usia muda (Batu, 2016). Tenaga kerja usia muda dan terdidik yang berada di perkotaan memiliki kecenderungan untuk menganggur lebih tinggi dibandingkan dengan tenaga kerja terdidik yang berada di perdesaan (Aryati, et al,, 2014; Pratomo, 2017; Msigwa \& Kipesha, 2013; Putra \& Iskandar, 2018).

b. Ukuran Rumah Tangga (Household Size)

Ukuran rumah tangga merupakan salah satu faktor penting yang diduga menentukan terjadinya pengangguran usia muda dan pengangguran terdidik. Semakin besar ukuran rumah tangga, maka peluang untuk menjadi seorang pengangguran usia muda (Wardhana, et al., 2019) dan pengangguran terdidik (Khan \& Yousaf, 2013) akan semakin berkurang.

c. Jenis Kelamin

Angkatan kerja perempuan terdidik (Aryati, et al., 2014; Pratomo, 2017) dan usia muda (Msigwa \& Kipesha, 2013; Alawad, et al., 2020) memiliki kecenderungan menganggur yang lebih tinggi dibandingkan dengan lakilaki. Hasil serupa juga ditunjukkan oleh Ritonga (2019), bahwa tenaga kerja perempuan memiliki lama waktu mencari kerja yang lebih tinggi dibandingkan dengan laki-laki, salah satu kemungkinannya dikarenakan oleh stereotipe pasar kerja yang lebih mengutamakan tenaga kerja laki-laki karena memiliki fisik lebih kuat dan aman.

d. Umur

Aryati, et al., (2014) dalam penelitiannya menunjukkan bahwa umur merupakan variabel independen yang paling signifikan memengaruhi pengangguran terdidik setelah variabel status perkawinan. Kemungkinan mendapatkan pekerjaaan cenderung meningkat seiring dengan bertambahnya umur, namun setelah mencapai umur tertentu peluangnya menurun (Bairagya, 2015).

e. Status Perkawinan

Status pengangguran seorang angkatan kerja usia muda terdidik diduga dipengaruhi oleh status perkawinannya. Angkatan kerja berusia muda (Wardhana, et al., 2019; Gaffari \& Handayani, 2019; Alawad, et al., 2020) dan terdidik (Aryati, et al., 2014; Pratomo, 2017) yang berstatus belum kawin memiliki kecenderungan yang lebih tinggi untuk menganggur dibandingkan dengan mereka yang berstatus pernah kawin.

f. Pendidikan

Variabel pendidikan diduga memengaruhi terjadinya pengangguran pada usia muda terdidik. Semakin tinggi pendidikan seorang tenaga kerja usia muda (Putra \& Iskandar, 2018; Alawad, et al., 2020) dan terdidik (Kurniawan \& Handayani, 2013; Gebisa \& Etana, 2019), maka akan semakin kecil 
peluangnya untuk menjadi seorang pengangguran.

g. Jurusan Pendidikan

Menurut Aprilliofany (2020), klasifikasi jurusan dari pendidikan terakhir yang ditempuh seorang tenaga kerja berpengaruh secara signifikan terhadap terjadinya pengangguran.

h. Pengalaman Mengikuti Pelatihan/Kursus Kerja

Tenaga kerja terdidik yang menyatakan pernah mengikuti pelatihan/kursus kerja dan atau program peningkatan keterampilan cenderung lebih cepat mendapatkan pekerjaan dibandingkan dengan tenaga kerja terdidik yang tidak pernah mengikuti pelatihan/kursus kerja (Najoan, 2018; Khan \& Yousaf, 2013).

\section{METODOLOGI}

Penelitian ini menggunakan raw data Survei Angkatan Kerja Nasional (Sakernas) Agustus 2019 di provinsi Banten. Unit analisis penelitian yang digunakan yaitu penduduk usia muda 15-29 tahun dengan ijazah pendidikan terakhir minimum SMA/Sederajat. Variabel dependen dan independen yang digunakan dalam penelitian beserta pengkategoriannya ditunjukkan pada Tabel 1 sebagai berikut:

Tabel 1. Variabel-variabel dalam penelitian

\begin{tabular}{|c|c|c|c|}
\hline No. & Variabel & & Kategori \\
\hline (1) & (2) & & (3) \\
\hline \multicolumn{4}{|c|}{ Variabel Dependen } \\
\hline & \multirow{2}{*}{ Status Bekerja } & $1=$ & Bekerja* \\
\hline & & $2=$ & Pengangguran \\
\hline \multicolumn{4}{|c|}{ Variabel Independen } \\
\hline \multirow{2}{*}{1} & \multirow{2}{*}{$\begin{array}{l}\text { Wilayah tempat } \\
\text { tinggal }\end{array}$} & $1=$ & Perkotaan* \\
\hline & & $2=$ & Perdesaan \\
\hline \multirow{3}{*}{2} & \multirow{3}{*}{$\begin{array}{l}\text { Ukuran rumah } \\
\text { tangga }\end{array}$} & $1=$ & $\begin{array}{l}\text { Kecil (jumlah anggota } \\
\text { rumah tangga }<5 \text { ) }\end{array}$ \\
\hline & & $2=$ & $\begin{array}{l}\text { Sedang (jumlah anggota } \\
\text { rumah tangga 5-6) }\end{array}$ \\
\hline & & $3=$ & $\begin{array}{l}\text { Besar (jumlah anggota } \\
\text { rumah tangga }>6 \text { )* }\end{array}$ \\
\hline \multirow{2}{*}{3} & \multirow{2}{*}{ Jenis kelamin } & $1=$ & Laki-laki* \\
\hline & & $2=$ & Perempuan \\
\hline
\end{tabular}

\begin{tabular}{|c|c|c|c|}
\hline 4 & Umur & \multicolumn{2}{|c|}{ Numerik } \\
\hline \multirow[b]{2}{*}{5} & \multirow{2}{*}{$\begin{array}{l}\text { Status } \\
\text { Perkawinan }\end{array}$} & $1=$ & Belum kawin* \\
\hline & & $2=$ & $\begin{array}{l}\text { Pernah kawin (kawin, cerai } \\
\text { mati, dan cerai hidup) }\end{array}$ \\
\hline \multirow{2}{*}{6} & \multirow{2}{*}{ Pendidikan } & $1=$ & SMA \\
\hline & & $2=$ & $>\mathrm{SMA}^{*}$ \\
\hline \multirow{3}{*}{7} & \multirow{3}{*}{$\begin{array}{l}\text { Jurusan } \\
\text { Pendidikan }\end{array}$} & $1=$ & Teknik \\
\hline & & $2=$ & Non teknik \\
\hline & & $3=$ & Lainnya* \\
\hline \multirow[t]{2}{*}{8} & \multirow{2}{*}{$\begin{array}{l}\text { Pengalaman } \\
\text { mengikuti } \\
\text { pelatihan/kursus } \\
\text { kerja }\end{array}$} & $1=$ & $\mathrm{Ya}^{*}$ \\
\hline & & $2=$ & Tidak \\
\hline
\end{tabular}

* Kategori referensi

\section{Prosedur Analisis}

Penelitian ini menggunakan aplikasi $\mathrm{R}$ dengan paket caret serta Microsoft Excel dalam melakukan pengolahan data. Adapun prosedur analisis dalam menentukan determinan pengangguran terdidik usia muda di provinsi Banten 2019 ialah sebagai berikut:

1. Melakukan preprocessing data

2. Melakukan analisis secara deskriptif

3. Mengestimasi parameter regresi logistik biner

4. Melakukan uji signifikansi parameter secara simultan

5. Melakukan uji signifikansi parameter secara parsial

6. Menguji kebaikan model (Goodness of fit test)

7. Menginterpretasi odds ratio

\section{PEMBAHASAN}

Gambaran umum pengangguran terdidik ia muda Provinsi Banten sebagai berikut :

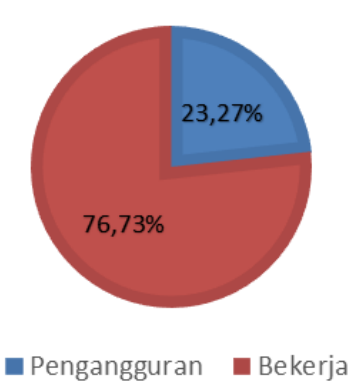

Gambar 1. Persentase Pengangguran Terdidik Usia Muda Provinsi Banten Tahun 2019 
Perbandingan antara penduduk yang berstatus pengangguran terdidik usia muda dengan penduduk yang bekerja memiliki perbedaan yang cukup besar. Dapat dilihat dari gambar 1 bahwa persentase penduduk yang berstatus pengangguran terdidik usia muda sebesar $23,27 \%$ sedangkan persentase penduduk yang berstatus bekerja sebesar $76,73 \%$.

Setelah melakukan pengolahan data dengan memasukkan seluruh variabel maka diperoleh nilai estimasi untuk parameter regresi logistik biner sebagai berikut :

Tabel 2. Hasil analisis regresi logistik biner

\begin{tabular}{|c|c|c|c|}
\hline Variabel & $\hat{\beta}$ & $\exp (\widehat{\beta})$ & p-value \\
\hline Konstanta & $-426,320$ & 0,0141 & 0,000001 \\
\hline $\begin{array}{l}\text { Wilayah tempat } \\
\text { tinggal }(\mathrm{X} 1)\end{array}$ & $-0,50852$ & 0,6014 & $0,000144 *$ \\
\hline \multicolumn{4}{|l|}{$\begin{array}{l}\text { Ukuran rumah } \\
\text { tangga }(\mathrm{X} 2)\end{array}$} \\
\hline Kecil & $-0,17577$ & 0,8388 & 0,455048 \\
\hline Sedang & $-0,12752$ & 0,8803 & 0,599516 \\
\hline $\begin{array}{l}\text { Jenis Kelamin } \\
\text { (X3) }\end{array}$ & 0,34172 & 14,074 & $0,006329 *$ \\
\hline Umur (X4) & 0,24235 & 12,742 & $0,000000^{*}$ \\
\hline $\begin{array}{l}\text { Status } \\
\text { Perkawinan (X5) }\end{array}$ & 116,982 & 32,214 & $0,000000^{*}$ \\
\hline Pendidikan (X6) & 0,30763 & 13,602 & 0,081988 \\
\hline \multicolumn{4}{|l|}{$\begin{array}{l}\text { Jurusan } \\
\text { Pendidikan (X7) }\end{array}$} \\
\hline Non-teknik & $-0,17233$ & 0,8417 & 0,692784 \\
\hline Teknik & $-0,10498$ & 0,9003 & 0,814259 \\
\hline $\begin{array}{l}\text { Pengalaman } \\
\text { mengikuti } \\
\text { pelatihan/kursus } \\
\text { kerja }(\mathrm{X} 8)\end{array}$ & $-0,09252$ & 0,8078 & 0,622374 \\
\hline
\end{tabular}

Berdasarkan tabel diatas diperoleh model persamaan regresi logistik biner sebagai berikut:

$$
\begin{aligned}
g(x)=-4,26320 & -0,50852 X_{1}-0,17577 X_{2 \text { Kecil }} \\
- & 0,12752 X_{2 \text { Sedang }}+0,34172 X_{3} \\
+ & 0,24235 X_{4}+1,16982 X_{5} \\
+ & 0,30763 X_{6}-0,17233 X_{7 \text { Non-teknik }} \\
& -0,10498 X_{7 \text { Teknik }}-0,09252 X_{8}
\end{aligned}
$$

Selanjutnya dilakukan pengujian parameter secara simultan dan diperoleh nilai uji statistik $\mathrm{G}^{2}$ yang dihasilkan sebesar -962,77 dengan $p$-value bernilai 0,0000 . Karena nilai $p$-value $<0,05$ maka tolak $\mathrm{H}_{0}$ yang berarti terdapat minimal satu variabel prediktor yang memiliki konstribusi yang signifikan terhadap variabel respon. Setelah melakukan uji simultan maka langkah selanjutnya akan dilakukan pengujian signifikansi untuk masing-masing parameter dalam model. Hasil diperoleh variabel yang signifikan berpengaruh terhadap pengangguran terdidik berusia muda yaitu variabel Wilayah tempat tinggal (X1), Jenis Kelamin (X3), Umur (X4), dan Status Perkawinan (X5). Selain itu, juga dilakukan pengujian kebaikan model menggunakan uji Hosmer and Lemeshow Berdasarkan hasil pengujian yang diperoleh nilai chi-square sebesar 11,828 dengan p-value sebesar 0,159. Karena nilai p-value lebih dari 0,05 maka keputusan yang dapat diambil adalah gagal tolak $\mathrm{H}_{0}$. Dengan demikian, dapat disimpulkan bahwa model yang digunakan sesuai dalam menjelaskan antara pengangguran usia muda terdidik Provinsi Banten dengan variabel-variabel prediktor pada model.

Hasil analisis dengan regresi logistik biner menunjukkan bahwa nilai odds ratio untuk variabel wilayah tempat tinggal ialah sebesar 1,6628. Nilai tersebut menunjukkan bahwa seorang pemuda yang tinggal di wilayah perkotaan memiliki kecenderungan untuk menjadi pengangguran terdidik sebesar 1,6628 kali lebih besar dibandingkan dengan seorang pemuda yang tinggal di wilayah perdesaan. Hasil ini sejalan dengan beberapa penelitian yang telah dilakukan (Aryati, Sunaryanto, \& Sunoto, 2014; Pratomo, 2017; Msigwa \& Kipesha, 2013; Putra \& Iskandar, 2018) di mana hasilnya menyatakan bahwa tenaga kerja berusia muda yang bermukim/tinggal di perkotaan memiliki kecenderungan lebih tinggi untuk menjadi seorang pengangguran terdidik dibandingkan dengan tenaga kerja yang berada di perdesaan. Kemungkinan yang menyebabkan tingginya peluang seorang tenaga kerja usia muda untuk menjadi pengangguran terdidik di perkotaan dikarenakan dampak dari besarnya arus urbanisasi atau migrasi dari desa ke kota 
(Pratomo, 2017). Banyak penduduk yang sengaja melakukan migrasi dari desa ke kota dengan tujuan untuk mencari pekerjaan dengan alasan sudah berkembangnya perekonomian di kota (Ernawati \& Romika, 2014).

Untuk variabel jenis kelamin diperoleh odds ratio sebesar 1,4074. Hal tersebut menunjukkan bahwa seseorang perempuan memiliki kecenderungan untuk tidak menjadi pengangguran terdidik sebesar 1,4074 kali lebih besar dibandingkan dengan laki-laki. Hal ini sejalan dengan penelitian dari Hartoko (2019) yang menyatakan bahwa lama waktu yang dibutuhkan laki-laki lebih panjang daripada perempuan, sehingga laki-laki cenderung untuk menganggur daripada perempuan. Hal tersebut sesuai dengan data dari Kementrian Pemberdayaan Perempuan dan Perlindunggan Anak (2016) yang menyatakan bahwa perempuan biasanya lebih mudah terserap dalam pekerjaan dengan produktivitas rendah. Masa pencarian kerja perempuan yang lebih singkat daripada laki-laki menunjukkan bahwa perempuan lebih mudah terserap oleh lapangan pekerjaan walaupun pekerjaan dengan produktivitas rendah seperti buruh pabrik dan pekerja rumahan. Hal tersebut menyebabkan tenaga kerja terdidik perempuan cenderung lebih mudah mencari pekerjaan daripada tenaga kerja terdidik laki-laki.

Sedangkan untuk nilai odd ratio pada variabel umur diperoleh 1,2742. Dari nilai tersebut dapat diartikan bahwa tiap penambahan umur 1 tahun akan menambah kecenderungan 1,2742 kali lebih besar untuk tidak menjadi pengangguran terdidik. Hal ini sejalan dengan penelitian dari Wardhana, et al. (2019) yang menemukan bahwa terdapat pengaruh umur seseorang terhadap status pekerjaannya, Hal tersebut dikarenakan penduduk lebih dewasa dianggap lebih terkait pengalaman kerja dan keterampilan sehingga lebih siap bersaing dalam pasar kerja. Selain itu, Pratomo (2017) juga mengemukakan bahwa tenaga kerja usia lebih dewasa cenderung memandang pekerjaan sebagai sebuah keharusan karena memiliki tanggung jawab untuk turut kontribusi dalam menopang kebutuhan ekonomi baik diri sendiri maupun keluarga. Seperti yang dikemukakan oleh Priyono (2015) penduduk usia muda yang memiliki pendidikan yang relatif tinggi cenderung lebih memilih menganggur untuk menunggu mendapatkan pekerjaan yang cocok ataupun yang sesuai dengan bidang yang mereka tekuni selama ini.

Untuk variabel status perkawinan diperoleh odds ratio sebesar 3,2214. Hal tersebut menunjukkan bahwa seseorang yang berstatus pernah kawin memiliki kecenderungan untuk tidak menjadi pengangguran terdidik sebesar 3,2214 kali lebih besar dibandingkan dengan seseorang yang berstatus belum kawin. Hal ini sejalan dengan penelitian dari Pratomo (2017) yang mengemukakan bahwa seseorang yang belum menikah akan cenderung menjadi penganggur jika dibandingkan dengan seseorang yang sudah menikah. Hal tersebut dikarenakan seseorang yang telah menikah, maka orang tersebut memiliki tanggungan keluarga, baik istri, suami atau anak. Selain itu, Wardhana, et al. (2019) bahwa angkatan kerja muda yang sudah menikah akan menurunkan peluang menjadi pengangguran usia muda dibanding yang belum menikah, individu yang belum menikah relatif belum memiliki beban untuk menafkahi anggota keluarganya. Adyaksa (2020) berpendapat bahwa seseorang yang belum menikah memilik probabilitas yang lebih besar untuk menjadi pengangguran daripada yang pernah menikah.

\section{KESIMPULAN DAN SARAN}

Berdasarkan hasil penelitian dapat disimpulkan bahwa variabel wilayah tempat tinggal, jenis kelamin, umur, dan status perkawinan berpengaruh signifikan terhadap status bekerja angkatan kerja usia muda terdidik di Provinsi Banten. Angkatan kerja usia muda terdidik yang tinggal di perkotaan, berjenis kelamin laki-laki, dan berstatus belum kawin memiliki kecenderungan lebih besar untuk menjadi pengangguran. Sedangkan penambahan satu tahun umur pada angkatan kerja usia muda terdidik menurunkan kecenderungan untuk menjadi pengangguran.

Berdasarkan temuan penelitian ini terdapat beberapa saran yang diberikan yaitu pemerintah daerah setempat hendaknya memaksimalkan pemanfaatan sumber daya di daerah perkotaan agar terciptanya lapangan pekerjaan yang semakin luas. Selain itu, pemerintah setempat 
juga akan lebih baik apabila mengarahkan penduduknya untuk menciptakan lapangan pekerjaan. Pemerintah juga hendaknya mengadakan pameran bursa kerja untuk memudahkan penyebarluasan informasi lowongan pekerjaan agar para pencari kerja mendapatkan pekerjaan yang sesuai dengan keterampilan dan keinginan yang dimiliki. Perlu adanya kerja sama antara pemerintah, lembaga pendidikan, dan dunia usaha untuk menciptakan suatu program yang dapat meningkatkan keterampilan dan menambah pengalaman kerja seperti melalui program magang maupun program-program pelatihan di bidang tertentu. Selain itu, dari sisi angkatan kerja terdidik terutama yang masih lulusan baru (fresh graduate) baik jenjang SMA/Sederajat maupun perguruan tinggi untuk tidak berfokus mencari pekerjaan mapan dan ideal. Hal utama yang perlukan saat itu yakni pengalaman kerja untuk bekal pekerjaan baru yang lebih baik nanti.

\section{DAFTAR PUSTAKA}

[1] Adyaksa, Fahreza Ferdian (2019), Analisis Faktor-Faktor yang Mempengaruhi Pengangguran Terdidik di Indonesia Tahun 2018, E-Jurnal Ilmu Ekonomi dan Bisnis Universitas Brawijaya.

[2] Alawad, A, S, Kreishan, F, \& Selim, M, (2020), Determinants of Youth Unemployment: Evidence from Jordan, International Journal of Economics and Business Administration, 152-165,

[3] Aprilliofany, A, (2020), Analisis Penyebab Pengangguran Lulusan Sekolah Kejuruan di Jawa Barat dan Garut, Jurnal Litbang Sukowati, 57-68,

[4] Aryati, F,, Sunaryanto, H, \& Sunoto, (2014), Jurnal Ekonomi dan Perencanaan Pembangunan (JEPP), 70-79,

[5] Bairagya, I, (2015), Socio-Economic Determinants of Educated Unemployment in India, The Institute for Social and Economic Change,

[6] Batu, M, M, (2016), Determinants of Youth Unemployment in Urban Areas of, International Journal of Scientific and Research Publications, Volume 6, Issue 5, 343-350,
[7] Badan Pusat Statistik, 2012, Analisis Statistik Sosial (Bonus Demografi dan Pertumbuhan Ekonomi).

[8] Badan Pusat Statistik, 2019, Keadaan Ketenagakerjaan Banten Agustus 2019.

[9] Badan Pusat Statistik, 2019, Statistik Pemuda Indonesia 2019.

[10] David W, Hosmer, Lemeshow, S, \& Rodney X,, Sturdivant, (2000), Applied logistic regression, New York: Wiley

[11]Ernawati, E., \& Romika, R. (2014). Strategi Pemerintah dalam Memperkecil Angka Pengangguran di Kecamatan Tampan Kota Pekanbaru (Doctoral dissertation, Riau University).

[12] Gaffari, A,, \& Handayani, D, (2019), Keputusan Usia Muda Yang Tidak Bekerja dan Tidak Terikat Pendidikan (Nee) dan Karakteristiknya di Indonesia, Jurnal Ekonomi 22(2), 76-91,

[13] Gebisa, D, A, \& Etana, N, G, (2019), Determinants of Graduate Youth Unemployment (A Case Study in West Shoa Zone, Ethiopia), International Journal of Islamic Business and Economics, 90-103,

[14] Hartoko, Y. (2019). Pengaruh Pendidikan, Pelatihan, Jenis Kelamin, Umur, Status Perkawinan, dan Daerah Tempat Tinggal terhadap Lama Mencari Tenaga Kerja Terdidik di Indonesia. Jurnal Pendidikan dan Ekonomi, 206.,

[15] International Labour Organization (ILO), 2007, Kajian Tentang Ketenagakerjaan Kaum Muda di Indonesia.

[16] Kementrian Pemberdayaan Perempuan dan Perlindunggan Anak. (2016). Statistik Gender Tematik: Potret Ketimpangan Gender dalam Ekonomi. Jakarta: Kementrian Pemberdayaan Perempuan dan Perlindungan Anak.

[17]Khan, T,, \& Yousaf, F, (2013), Unemployment Duration of First Time Job Seekers: A Case Study of Bahawalpur, Asian Journal of Economic Modelling, 8-19,

[18] Kurniawan, A, P, \& Handayani, H, R, (2013), Analisis Lama Mencari Kerja Bagi Tenaga Kerja Terdidik di Kabupaten Purworejo, Diponegoro Journal of Economics, 1-11, 
[19] Maryati, Sri, "Dinamika Pengangguran Terdidik: Tantangan Menuju Bonus Demografi di Indonesia," Economica: Jurnal Program Studi Pendidikan Ekonomi STKIP PGRI Sumatera Barat, vol, 3, no, 2, 2015, pp, 124-136, doi:10,22202/economica,2015,v3,i2,249.

[20] Msigwa, R, \& Kipesha, E, F, (2013), Determinants of Youth unemployment in Developing Countries: Evidences from Tanzania, Journal of Economics and Sustainable Development, 67-76,

[21]Najoan, P, W, (2018), Analisis Faktor Yang Mempengaruhi Lama Mencari Pekerjaan Terhadap Tenaga Kerja Terdidik di Indonesia 2016,

[22] Pratomo, D, S, (2017), Fenomena Pengangguran Terdidik di Indonesia, Suistanable Competitive Advantage-7 (SCA7) FEB Unsoed, 642-648,

[23]Priyono, Edy, 2015, Pengangguran Muda dan Solusinya, Pusat Kajian Kebijakan Publik Akademika Universitas Indonesia

[24]Putra, M, E, \& Iskandar, D, D, (2018), Determinan Status Pengangguran Usia Muda di Perkotaan dan Pedesaan di Indonesia, Jurnal Ilmu Ekonomi Terapan, 44-70,

[25]Putri, K, \& Aimon, H, (2019), Analisis Determinan Tenaga Kerja Terdidik Yang Bekerja pada Lapangan Pekerjaan Non Primer di Sumatera Barat, Jurnal Kajian Ekonomi dan Pembangunan, 823-832,

[26]Ritonga, M, A, (2019), Analisis Faktorfaktor Yang Memengaruhi Lama Mencari Kerja Bagi Tenaga Kerja Terdidik di Kota Medan,

[27] Wardhana, A, Kharisma, B, \& Ibrahim, Y, F, (2019), Pengangguran Usia Muda di Jawa Barat (Menggunakan Data Sakerna), EJurnal Ekonomi dan Bisnis Universitas Udayana 8,9, 1049-1062, 